\title{
GLYCOLYTIC ENZYMES IN THE SPERMATOZOA AND CYTOPLASMIC DROPLETS OF BULL, BOAR AND RAM, AND THEIR LEAKAGE AFTER SHOCK
}

\author{
R. A. P. HARRISON and I. G. WHITE* \\ A.R.C. Unit of Reproductive Physiology and Biochemistry, Cambridge $†$
}

(Received 7th Fune 1971, accepted 15th Fuly 1971)

\begin{abstract}
Summary. A method has been developed for the simultaneous isolation of spermatozoa and cytoplasmic droplets from bull, boar and ram semen. The glycolytic enzymes, hexokinase (HK), glucose phosphate isomerase (GPI) and lactate dehydrogenase (LDH) were demonstrated in both types of particle: on a per particle basis compared with spermatozoa, droplets contained similar quantities of GPI, less HK and only one-tenth the amount of LDH. The HK was partly bound while the GPI was entirely soluble in both. The LDH was partly bound in spermatozoa but soluble in droplets.

Suspensions of spermatozoa and cytoplasmic droplets were subjected to sudden cooling, freezing or hypo-osmotic shock, and leakage of GPI, $\mathrm{HK}$ and $\mathrm{LDH}$ into the extracellular medium was measured. Both spermatozoa and droplets released glycolytic enzymes during the treatments, but the droplets were more fragile than the spermatozoa. The proportion of loss varied between enzymes, as well as between droplet and spermatozoon; considerable GPI and little HK was released from both, whereas much LDH was lost from droplets but hardly any from spermatozoa.

The activities of these three glycolytic enzymes were also measured in seminal plasma from bull, boar and ram. The ratios of the activities found were compared with those in droplets or spermatozoa from the same species. It is suggested that much of the glycolytic enzyme activity in seminal plasma arises from disintegrated cytoplasmic droplets rather than from spermatozoa.
\end{abstract}

\section{INTRODUCTION}

When spermatozoa are cooled too rapidly or frozen without added protective agents, they suffer irreversible and deleterious changes which lead to loss of motility and fertilizing capacity; the effect of rapid cooling is known as cold shock. Many studies of cold shock and deep-freezing have been made, concerning causative factors, the changes produced in spermatozoa, and the action of protective agents (see Bishop \& Walton, 1960b; Mann, 1964, p. $356 \mathrm{ff}$.). In recent years, interest has been focused on the loss of important substances

* Present address: Department of Veterinary Physiology, University of Sydney, Sydney, Australia.

$\dagger$ Postal address: Animal Research Station, 307 Huntingdon Road, Cambridge CB3 0JQ. 
such as cations, enzymes and other material from the spermatozoon during these treatments (Graham \& Pace, 1967; Pickett \& Komarek, 1967; Murdoch \& White, 1968; Pursel, Johnson \& Gerrits, 1968; Quinn \& White, 1968; Pursel, Johnson \& Gerrits, 1969; Quinn, White \& Cleland, 1969).

During a study of methods for washing mammalian spermatozoa (Harrison $\&$ White, 1972), observations on leakage of glycolytic enzymes suggested that the free-lying cytoplasmic droplets as well as the spermatozoa in semen might contain glycolytic enzymes which were readily released into the extracellular medium. Dott \& Dingle (1968) have shown that the droplets are fragile structures, containing lysosomal enzymes which are also found in spermatozoa. Garbers, Wakabayashi \& Reed (1970) have confirmed the presence of lysosomal enzymes in droplets and have also demonstrated the presence in them of low levels of lactate dehydrogenase and aldolase.

In view of the possibility that leakage of intracellular glycolytic enzymes in semen after shock might occur from cytoplasmic droplets as well as from spermatozoa, a study was made of some glycolytic enzymes in spermatozoa and droplets and their behaviour after sudden cooling, freezing or hypo-osmotic shock. A preliminary report of these findings has been published (Harrison \& White, 1969).

\section{MATERIALS AND METHODS}

Sources of chemicals, semen collection and the preparation of milk diluent were as described previously (Harrison \& White, 1972).

Isolation of spermatozoa and cytoplasmic droplets (for scheme see Text-fig. 1)

Semen was diluted with milk diluent at $25^{\circ} \mathrm{C}$ to a sperm density of 1 to $2 \times 10^{8} \mathrm{cells} / \mathrm{ml}$. This was equivalent to one part of semen to six parts of diluent for bull and 'concentrated' boar semen, and one part of semen to fourteen parts of diluent for ram semen.

The diluted semen was placed in a water-jacketed container (total volume 600 to $1000 \mathrm{ml}$ ) and slowly cooled overnight from $25^{\circ} \mathrm{C}$ to $4^{\circ} \mathrm{C}$ in a cold-room. All further operations in the isolation procedure were carried out at $4^{\circ} \mathrm{C}$.

Next morning the diluted semen was gently but thoroughly resuspended and centrifuged at $400 \mathrm{~g}$ for $15 \mathrm{~min}$. The supernatant, which was retained, was drawn off carefully to avoid damage to the suspended cytoplasmic droplets.

The sedimented spermatozoa were twice gently resuspended and recentrifuged at $400 \mathrm{~g}$ for $15 \mathrm{~min}$ in a medium containing $200 \mathrm{~mm}$-sucrose, $31 \mathrm{~mm}$ $\mathrm{NaCl}, 19 \mathrm{~mm}-\mathrm{NaH}_{2} \mathrm{PO}_{4}$ and $5 \mathrm{~mm}-\mathrm{KOH}$, adjusted to $\mathrm{pH} 7.0$ with $\mathrm{NaOH}$; the final sperm pellet was used for estimation of enzyme activities or for experiments on shocking. During the washing, the densities of the sperm suspensions were no greater than $2 \times 10^{8}$ cells $/ \mathrm{ml}$.

The supernatant from the initial centrifugation contained the majority of the cytoplasmic droplets and was centrifuged at $1000 \mathrm{~g}$ for $20 \mathrm{~min}$ to sediment all the remaining spermatozoa-under these conditions, practically all the droplets remained in suspension. The supernatant was removed carefully, avoiding disturbance of the pellet and damage to the droplets, and finally centrifuged at 
$4000 \mathrm{~g}$ for $30 \mathrm{~min}$. The loose pellet left after careful removal of this final supernatant was not washed further but used directly for estimation of enzyme activities or for experiments on shocking. It consisted almost entirely of morphologically intact cytoplasmic droplets.

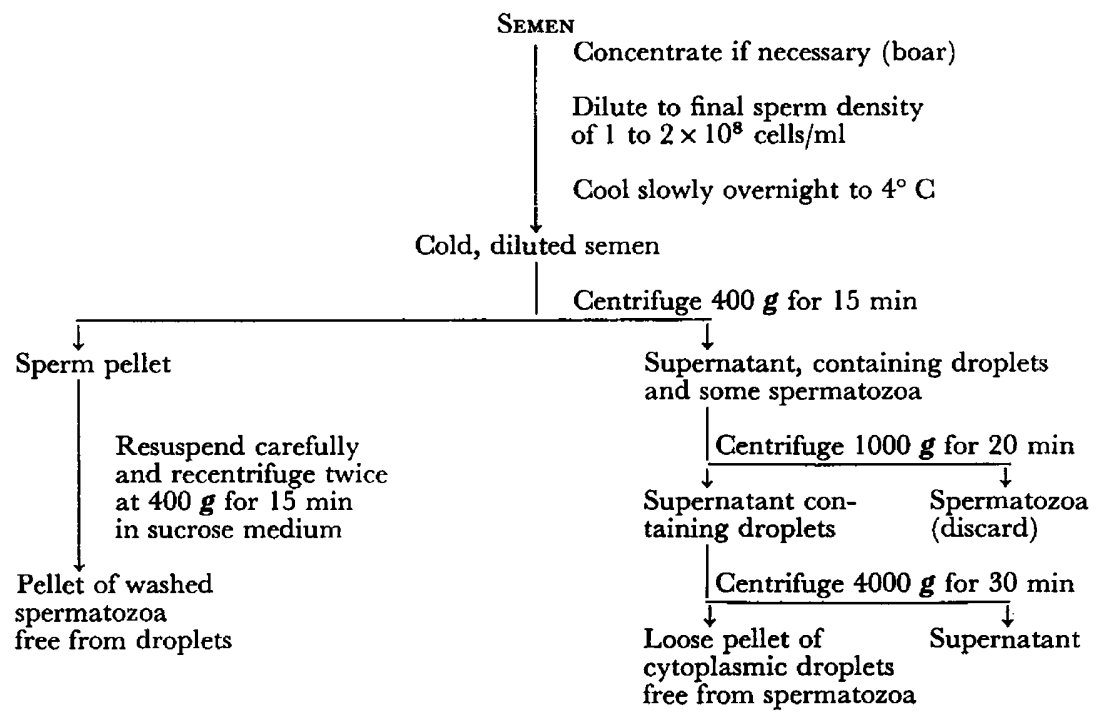

TExr-FIG. 1. Scheme for isolation of spermatozoa and cytoplasmic droplets. An M.S.E. Super Minor centrifuge with $50-\mathrm{ml}$ tubes and a swing-out head was used in the cold room at $4^{\circ} \mathrm{C}$. All centrifugal field values were calculated to the bottom of the tube.

\section{Estimation of enzymes in spermatozoa and droplets}

The final pellets of isolated particles were resuspended at $0^{\circ} \mathrm{C}$ in the sucrose medium used to wash the spermatozoa; the suspensions were sonicated (using a Kerry's Ultrasonic Cell Disruptor K 100 at $50 \mathrm{~W}$ input) to give complete homogenization ( $1 \mathrm{~min}$ for droplets, $3 \mathrm{~min}$ for spermatozoa). Precautions were taken to avoid heating the samples. The homogenates were centrifuged at $30,000 \mathrm{~g}$ for $25 \mathrm{~min}$ at $4^{\circ} \mathrm{C}$, and enzyme assays were performed on the homogenates and the $30,000 \mathrm{~g}$ supernatants to measure the total and soluble activities, respectively.

During isolation procedures, samples of fresh semen, cold diluted semen and the final supernatant after sedimentation of droplets were centrifuged at $30,000 \mathrm{~g}$ for $25 \mathrm{~min}$ at $4^{\circ} \mathrm{C}$ or at $20^{\circ} \mathrm{C}$ (fresh semen only), and the supernatants assayed for enzyme activities as a measure of soluble seminal plasma enzymes and of leakage occurring during the cooling and isolation processes.

\section{Shocking of spermatozoa and droplets}

The final pellets of isolated particles were warmed in a water bath at $30^{\circ} \mathrm{C}$ and gently resuspended in Krebs-Ringer-fructose-phosphate medium (Mann, 1964, p. 347) at the same temperature.

The suspensions of droplets and spermatozoa were cold-shocked or frozen as follows: three 1.5-ml samples of each suspension were placed in small glass 
tubes and incubated at $30^{\circ} \mathrm{C}$ for $10 \mathrm{~min}$. One sample was then cooled as rapidly as possible to $0^{\circ} \mathrm{C}$ in an ice-water mixture and held there for $10 \mathrm{~min}$, another sample was rapidly frozen in a solid $-\mathrm{CO}_{2} / 2$-ethoxyethanol mixture at $-79^{\circ} \mathrm{C}$ and held there for $10 \mathrm{~min}$, and the third, control sample, remained at $30^{\circ} \mathrm{C}$. At the end of the 10 -min period, the two cooled samples were replaced in the $30^{\circ} \mathrm{C}$ water bath, warmed up as rapidly as possible and all three samples were incubated for a further $10 \mathrm{~min}$ at $30^{\circ} \mathrm{C}$. Finally all samples were centrifuged as described below.

Hypo-osmotic shock was effected by rapidly diluting samples of droplet or sperm suspensions at $30^{\circ} \mathrm{C}$ with four vol. of $50 \mathrm{~mm}$-potassium phosphate buffer $(\mathrm{pH} 7.0)$ containing $5 \mathrm{~mm}-\mathrm{mDTA}$ and $5 \mathrm{~mm}$-2-mercaptoethanol; control samples were similarly diluted in Krebs-Ringer-phosphate medium (Mann, 1964, p. 347). After dilution, the suspensions were well mixed, left to stand for 10 min, remixed and centrifuged as described below.

Since the object was to study the release of enzymes into the extracellular medium (i.e. leakage), only soluble fractions were assayed for activity, because only soluble enzymes could be involved in leakage. Thus, the samples and controls were centrifuged at $30,000 \mathrm{~g}$ for $25 \mathrm{~min}$ at $20^{\circ} \mathrm{C}$, and the supernatants removed and assayed. The total soluble activity present in the suspensions was estimated by sonicating them as above, centrifuging the homogenates at $30,000 \mathrm{~g}$ for $25 \mathrm{~min}$ at $20^{\circ} \mathrm{C}$ and assaying the supernatants. A centrifuging temperature of $20^{\circ} \mathrm{C}$ was considered sufficiently high to avoid cold shock (Wales \& White, 1959) but low enough to avoid undue denaturation of enzymes in a cell-free environment.

\section{Enzyme assays}

Fractions were assayed for hexokinase (HK, EC 2.4.1.1), glucose phosphate isomerase (GPI, EC 5.3.1.9) and lactate dehydrogenase (LDH, EG 1.1.1.2.7) activities. The procedure used was as described previously by Harrison \& White (1972). All assays were performed in duplicate at $37^{\circ} \mathrm{C}$ in a vol. of $1 \mathrm{ml}$. One unit of enzyme activity converts $1 \mu \mathrm{mol}$ substrate/min under the specified assay conditions. The assay systems used were (final concentrations): $\mathrm{HK}-100$ mM-tris $\mathrm{HCl}\left(\mathrm{pH} 7.4\right.$ at $37^{\circ} \mathrm{C}$ ), 1 mM-EDTA, $1 \mathrm{~mm}$-2-mercaptoethanol, 10 mM- $\mathrm{MgCl}_{2}, 2.5 \mathrm{~mm}-\mathrm{ATP}$ (neutralized), $1 \mathrm{~mm}$-glucose, $0.5 \mathrm{~mm}-\mathrm{NADP}^{+}$and 2 $\mu \mathrm{g}(0.56$ units) crystalline glucose-6-phosphate dehydrogenase/ml; GPI-100 mM-tris $\mathrm{HCl}\left(\mathrm{pH} 7.4\right.$ at $\left.37^{\circ} \mathrm{C}\right), 1 \mathrm{~mm}$-EDTA, 1 mM-2-mercaptoethanol, $1 \mathrm{~mm}$ -

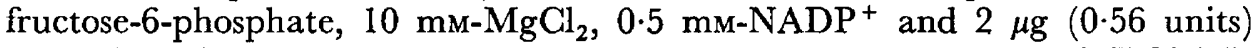
crystalline glucose-6-phosphate dehydrogenase/mI; LDH-100 mm-tris $\mathrm{HCl}$ ( $\mathrm{pH}$ 7.4 at $37^{\circ} \mathrm{C}$ ), $1 \mathrm{~mm}$-EDTA, $1 \mathrm{~mm}$-2-mercaptoethanol, $2 \mathrm{~mm}$-pyruvate and 0.25 mM-NADH.

\section{Particle counts}

Samples were diluted with formol-saline and duplicate counts of spermatozoa and cytoplasmic droplets made using a Neubauer Improved bright line haemocytometer with phase contrast illumination at a magnification of $\times 900$. 


\section{RESULTS}

\section{Glycolytic enzymes in spermatozoa and cytoplasmic droplets}

Suspensions of isolated cytoplasmic droplets and washed spermatozoa from bull, boar and ram were prepared for enzyme estimations on two occasions. Photographs of the preparations from boar are shown in Plate 1; the preparations from the other species were similar. Table 1 gives the results of GPI, LDH and HK analyses on each of the sperm and droplet suspensions, together with the percentage contamination by the other particle. All values for enzyme activity were corrected for such contamination if it exceeded $4 \%$ on a particle basis.

Apart from preparation (a) from boar semen, which was the first of the series, the method for isolating droplets and spermatozoa proved successful. Boar semen was the most difficult to work with because the difference in density between spermatozoon and droplet was less in this species than in the others. Recovery of the droplets was routinely between $20 \%$ and $40 \%$, so that relatively large amounts of material could be prepared. Checks for leakage of GPI during the isolation procedures showed little or none during centrifugation. Final resuspension of the droplets, however, tended to cause damage, as revealed by the appearance of extraparticulate GPI activity, although this was not necessarily accompanied by morphological changes. For this reason, the droplet preparations were not washed after resuspension but corrections were made for measured contamination by seminal plasma enzymes.

It was clearly demonstrated that the free-lying cytoplasmic droplets as well as the spermatozoa of all three species contained glycolytic enzymes and that the amounts in the droplet relative to the spermatozoon could be high; this was particularly true of GPI.

In all cases, the GPI content of the droplet was equal to or greater than that of the spermatozoon, but its $\mathrm{LDH}$ content was about $10 \%$ of the sperm content. The amount of HK in the droplet varied with the species but was between $15 \%$ and $50 \%$ of that in the spermatozoon. In addition, the physical distribution of GPI and HK followed similar patterns in each particle, i.e. entirely soluble and partly bound, respectively. On the other hand, $\mathrm{LDH}$ was only $50 \%$ soluble in the spermatozoon, but almost completely soluble in the droplet.

A curious feature was the wide range of values for sperm GPI content found within species. The values given in Table 1 were in good agreement with values obtained in the other experiments, in which the HK and LDH contents of the spermatozoa of each species were very consistent, whereas the GPI content varied considerably. This could not be accounted for by damage to the spermatozoa because leakage of enzymes during preparation of the samples remained low.

\section{Leakage of glycolytic enzymes from spermatozoa and cytoplasmic droplets after shock}

The effects of sudden cooling, freezing and hypo-osmotic shock on the spermatozoa and cytoplasmic droplets of bull, boar and ram are shown in Table 2 .

When spermatozoa were diluted in the milk diluent, left overnight in the cold and then washed, they reacted to cold shock and deep-freezing in a similar 


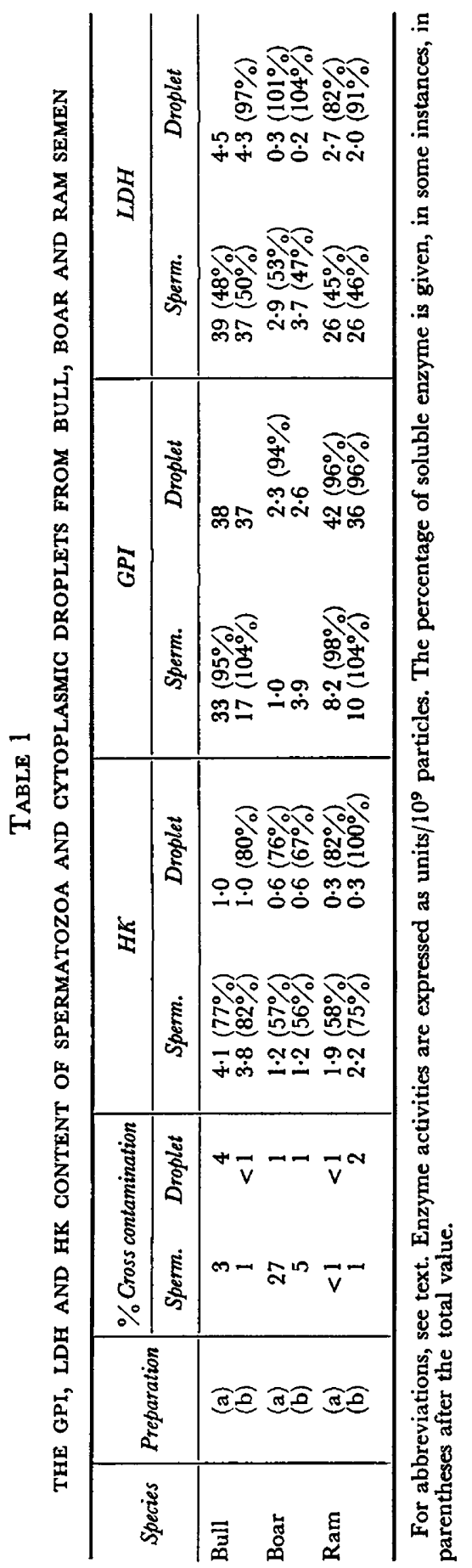




\section{PI.ATE}

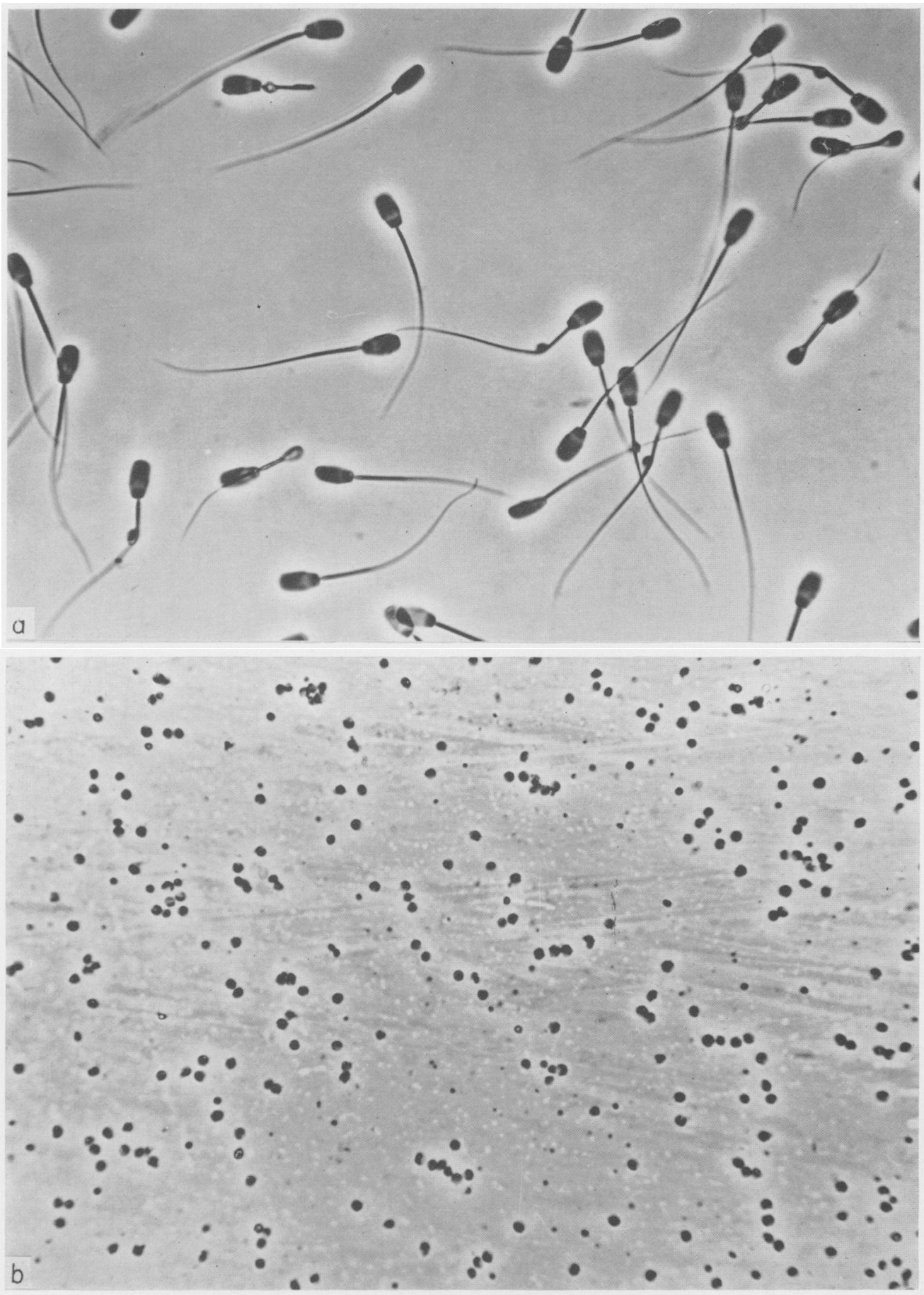

(a) Preparation of boar spermatozoa. Phase contrast, $\times 645$.

(b) Preparation of boar cytoplasmic droplets. Phase contrast, $\times 645$.

(Facing p. 110 ) 
manner to spermatozoa in neat semen or to spermatozoa washed by conventional methods, i.e. they rapidly lost motility. From part A of Table 2, it can be seen that leakage of GPI and LDH from spermatozoa of all three species occurred under these conditions, particularly during deep-freezing. The cytoplasmic droplets were highly sensitive to sudden cooling, and usually showed a greater loss of enzyme than did the spermatozoa under these conditions.

The effect of hypo-osmotic shock on each type of particle was studied because previous experiments (Harrison \& White, 1972) showed that leakage of enzymes

\section{TABLE 2}

THE PERCENTAGE OF GPI AND LDH IN THE EXTRACELIULAR MEDIUM OF SUSPENSIONS OF SPERMATOZOA AND CYTOPLASMIC DROPLETS AFTER (A) COLD SHOCK OR DEEP FREEZING AND (B) HYPO-OSMOTIC SHOCK

\begin{tabular}{|c|c|c|c|c|c|c|c|}
\hline \multirow[t]{2}{*}{ Species } & \multirow[t]{2}{*}{ Treatment } & \multicolumn{2}{|c|}{$\begin{array}{c}\% \text { Cross } \\
\text { contamination }\end{array}$} & \multicolumn{2}{|c|}{$G P I$} & \multicolumn{2}{|c|}{$L D H$} \\
\hline & & Sperm. & Droplets & Sperm. & Droplets & Sperm. & Droplets \\
\hline \multirow[t]{2}{*}{ Bull } & $\begin{array}{l}\text { A Control } \\
\text { Cold shocked } \\
\text { Deep frozen }\end{array}$ & 3 & 1 & $\begin{array}{r}9 \\
48 \\
91\end{array}$ & $\begin{array}{l}12 \\
80 \\
90\end{array}$ & $\begin{array}{r}2 \\
6 \\
13\end{array}$ & $\begin{array}{l}12 \\
64 \\
87\end{array}$ \\
\hline & $\begin{array}{l}\text { B Diluted in Ringer } \\
\text { Diluted in hypo-osmotic } \\
\text { phosphate }\end{array}$ & 1 & 1 & $\begin{array}{r}9 \\
44\end{array}$ & $\begin{array}{l}29 \\
84\end{array}$ & $\begin{array}{l}2 \\
6\end{array}$ & $\begin{array}{l}30 \\
84\end{array}$ \\
\hline \multirow[t]{2}{*}{ Boar } & $\begin{array}{l}\text { A Control } \\
\text { Cold shocked } \\
\text { Deep frozen }\end{array}$ & 13 & 1 & $\begin{array}{l}11 \\
30 \\
85\end{array}$ & $\begin{array}{r}4 \\
49 \\
84\end{array}$ & $\begin{array}{r}2 \\
4 \\
12\end{array}$ & $\begin{array}{r}5 \\
44 \\
71\end{array}$ \\
\hline & $\begin{array}{l}\text { B Diluted in Ringer } \\
\text { Diluted in hypo-osmotic } \\
\text { phosphate }\end{array}$ & 5 & 2 & $\begin{array}{r}7 \\
28\end{array}$ & $\begin{array}{l}16 \\
88\end{array}$ & $\begin{array}{l}2 \\
5\end{array}$ & $\begin{array}{l}15 \\
70\end{array}$ \\
\hline \multirow[t]{2}{*}{ Ram } & $\begin{array}{l}\text { A Control } \\
\text { Cold shocked } \\
\text { Deep frozen }\end{array}$ & 1 & 1 & $\begin{array}{r}7 \\
20 \\
96\end{array}$ & $\begin{array}{r}6 \\
19 \\
72\end{array}$ & $\begin{array}{l}1 \\
1 \\
4\end{array}$ & $\begin{array}{r}6 \\
16 \\
67\end{array}$ \\
\hline & $\begin{array}{l}\text { B Diluted in Ringer } \\
\text { Diluted in hypo-osmotic } \\
\text { phosphate }\end{array}$ & 1 & 1 & $\begin{array}{r}7 \\
17\end{array}$ & $\begin{array}{r}6 \\
69\end{array}$ & $\begin{array}{l}1 \\
1\end{array}$ & $\begin{array}{r}7 \\
57\end{array}$ \\
\hline
\end{tabular}

For abbreviations, see text. Values are the percentage of the total soluble enzyme present and are the average from two experiments.

occurred in sperm suspensions containing free droplets when these suspensions were washed with hypo-osmotic media. Part B of Table 2 shows that the droplets are the major source of such GPI and LDH leakage in all species examined, although there was some loss of GPI from spermatozoa.

A notable difference was observed between the droplets and the spermatozoa in the degree of leakage of LDH. There was very little leakage of LDH from bull, boar or ram spermatozoa after any treatment, but leakage from the droplets of all three species was extensive and paralleled the leakage of GPI.

Release of HK from ram spermatozoa and droplets was of an entirely different nature (figures not given): whereas the extracellular activity in the controls was relatively high, the effect of shock was relatively low. 
Soluble glycolytic enzymes in seminal plasma

Mean levels of HK, GPI and LDH found in seminal plasma from bull, boar and ram are presented in Table 3 . The activities are expressed per $10^{9}$ spermatozoa (to give a better comparison between species) and are compared with an

TABLE 3

A COMPARISON OF SOME GLYCOLYTIC ENZYME ACTIVITIES IN SEMINAL PLASMA, SPERMATOZOA AND CYTOPLASMIC DROPLETS OF THE BULL, BOAR AND RAM, WITH THE DISAPPEARANCE OF FREE-LYING CYTOPLASMIC DROPLETS

\begin{tabular}{l|c|l|c|c|c}
\hline Species & $\begin{array}{c}\text { Percentage } \\
\text { of droplets } \\
\text { disappeared }\end{array}$ & Seminal constituent & $H K$ & $G P I$ & $L D H$ \\
\hline Bull & 63 & Seminal plasma $\dagger$ & $1 \cdot 5$ & 20 & $1 \cdot 5$ \\
& & Droplets & $0 \cdot 97$ & 38 & $4 \cdot 4$ \\
Boar & \multirow{2}{*}{11} & Spermatozoa & $4 \cdot 0$ & 25 & 38 \\
& & Seminal plasma $\dagger$ & $0 \cdot 34$ & $1 \cdot 2$ & $0 \cdot 34$ \\
& & Droplets & $0 \cdot 57$ & $2 \cdot 5$ & $0 \cdot 28$ \\
Ram & Spermatozoa & $1 \cdot 2$ & $2 \cdot 5$ & $3 \cdot 3$ \\
& & Seminal plasma $\dagger$ & $0 \cdot 39$ & 27 & $1 \cdot 3$ \\
& & Droplets & $0 \cdot 30$ & 39 & $2 \cdot 4$ \\
& Spermatozoa & $2 \cdot 1$ & $9 \cdot 1$ & 26 \\
\hline
\end{tabular}

For abbreviations, see text. Enzyme activities are expressed as units $/ 10^{9}$ spermatozoa or droplets.

* Calculated by comparing the observed droplet/spermatozoon ratio with an assumed initial ratio of $1: 1$.

† Enzyme activity was measured per $\mathrm{ml}$ of centrifuged seminal plasma and divided by the sperm density of the original semen sample.

estimation of the percentage of disintegrated droplets, and the mean activities found in the droplets and spermatozoa (from Table 1). The ratios of GPI, HK and LDH activities found in seminal plasma were similar to those in the cytoplasmic droplets.

\section{DISCUSSION}

Mann (1964) has commented upon the likely intracellular origin of many enzymes found in seminal plasma, and suggested that spermatozoa may be one source. In this paper, we wish to draw attention to the free-lying cytoplasmic droplets as another likely source of seminal plasma enzymes.

The results presented above demonstrated clearly that significant levels of some glycolytic enzymes are present in cytoplasmic droplets as well as in spermatozoa from bull, boar and ram (although the ratio of droplet activity to sperm activity is variable). Moreover, the droplets will release considerable proportions of their contents into the surrounding medium on sudden cooling or on exposure to hypo-osmotic conditions.

These findings emphasize firstly the need to remove contaminating cytoplasmic droplets as completely as possible from sperm preparations when biochemical analyses are contemplated (the same, of course, applies to droplet preparations). From the work reported here and the work of Dott \& Dingle (1968), it seems 
that no generalization can be made regarding the distribution of enzymes between spermatozoon and droplet: every enzyme must be analysed individually.

Secondly, in any experiment on whole semen or even on washed spermatozoa, due consideration should be given to the possibility that the changes observed are connected with the free-lying cytoplasmic droplets rather than with the spermatozoa. This would be particularly relevant to gross biochemical measurements such as those of Graham \& Pace (1967), Pickett \& Komarek (1967) and Murdoch \& White (1968).

On leaving the testes, each spermatozoon has one attached cytoplasmic droplet. However, after ejaculation, the ratio of spermatozoa to droplets may be variable (Dott \& Dingle, 1968). In our experience, the approximate ratio is $1: 0.40$ for ram, $1: 0.33$ for bull and 1:0.77 for boar. With the proviso that boar droplets may appear morphologically intact while having lost much of their contents, the levels of glycolytic enzymes found in the seminal plasma correspond to the number of droplets that have disappeared. Thus, although much more rigorous studies would be needed to prove this theory, it seems possible that most, if not all, of the glycolytic enzyme activity in seminal plasma can be traced to disintegrated cytoplasmic droplets. The data in Table 3 suggest strongly that the soluble glycolytic enzymes in seminal plasma are, in fact, largely derived from droplets as a result either of leakage or of total disintegration. Leakage from otherwise intact spermatozoa would be likely to produce ratios of activity approximating those found extracellularly after shocking the spermatozoa, and leakage from distintegrated spermatozoa would give extracellular ratios far closer to the soluble enzyme ratios found within them.

We consider the uneven but consistent distribution of glycolytic enzymes between spermatozoon and cytoplasmic droplet to be a result of the origin of the droplet. According to Bishop \& Walton (1960a), the droplet is derived during spermateliosis from excess cytoplasm, after formation of the central fibres and mitochondrial helix. It would seem feasible, therefore, that droplet formation involves removal and inclusion of cytoplasmic regions only, within a certain amount of sperm membrane structures which eventually form the droplet membrane system (the droplet may also include remnants of the Golgi apparatus (Dott \& Dingle, 1968)). Assuming there is a spatial differentiation in the distribution of glycolytic enzymes within the sperm tail structure, differences and similarities in enzyme content between the spermatozoa and the droplets can be explained.

The common origin of the sperm and droplet membranes would explain similar physical properties of sperm and droplet $\mathrm{HK}$, since $\mathrm{HK}$ appears to be associated with membrane structures in bull, boar and ram spermatozoa (Harrison, unpublished observations). High levels of GPI in the droplet will occur if GPI is mainly found in the outer areas of the sperm cytoplasm. It would be concentrated in the droplet, leaving variable amounts in the sperm cytoplasm, thus explaining the variation in sperm GPI content between samples. The low levels and solubility of LDH in the droplet are explained if LDH is associated, either in a bound or a soluble form, with the mitochondria; this is not an unlikely possibility in view of the position of $\mathrm{LDH}$ in the metabolic 
pathway adjacent to entry into the Krebs cycle. Such an association would mean that only small amounts of LDH would be removed in the droplet (since mainly outer areas of cytoplasm are removed), and also that any LDH removed would be of a soluble nature.

This hypothesis is supported by the observations on enzyme leakage. The high extracellular activity of HK in control samples would be due to sensitivity of outer membranes to mechanical damage during resuspension; shock would not be expected to lead to actual fragmentation of these membranes. The high LDH and GPI leakage from the droplets as compared with the low LDH and high GPI leakage from the spermatozoa is in accord with the idea of soluble LDH compartmented with GPI in the droplets as compared with associated or partly bound LDH distributed towards the interior of the spermatozoa and GPI towards the exterior.

Our method of preparing cytoplasmic droplets appears to have some advantages over those of Dott \& Dingle (1968) and Garbers et al. (1970). By cooling and storing diluted semen, we have been able to isolate spermatozoa and droplets essentially undamaged and free from each other using a single ejaculate. Our method seems to be the only one applicable to boar semen, due to the tendency of boar droplets to aggregate (Harrison \& White, 1972), and can be easily modified to handle large volumes of material. It is less time-consuming than the method of Dott \& Dingle (1968) : apart from overnight storage, spermatozoa and droplets may be isolated in less than $3 \mathrm{hr}$. Moreover, the dilution and cooling of the semen may help to obviate the effects of any degradative processes occurring in the semen, although the use of a diluent containing protective milk solids may lead to coating of the particles with foreign substances. The sensitivity of the spermatozoa and cytoplasmic droplets towards cold shock after isolation using our protective medium is in accord with the observations that removal of egg-yolk from a suspension of spermatozoa also removes protection against cold shock (Kampschmidt, Mayer \& Herman, 1953), and suggests that spermatozoa freed from cytoplasmic droplets by our method retain at least some of the properties of freshly ejaculated spermatozoa.

Washing of the droplets after their isolation presents a problem. We have found that droplets may release a considerable proportion of their contents on resuspension, and this observation, together with experiments on washing spermatozoa (Harrison \& White, 1972), suggests that a preparation of droplets that has been washed may have lost most of the intraparticulate and some of the membrane material. Loss of the latter may not be so serious, but loss of the former could be very misleading in regard to the presence of soluble enzymes. Thus, when washed droplets are required, extreme caution should be exercised to avoid damage.

\section{ACKNOWLEDGMENTS}

We are grateful to Professor T. Mann for his advice and to Dr H. M. Dott and Dr I. Wilmut for collecting semen. One of us (I.G.W.) also wishes to thank the Wellcome Foundation for a travel grant and the Population Council for a fellowship. 


\section{REFERENGES}

Bishop, M. W. H. \& WALton, A. (1960a) Spermatogenesis and the structure of mammalian spermatozoa. In: Marshall's Physiology of Reproduction, 3rd edn, Vol. 1, Part 2, p.l. Ed. A. S. Parkes. Longmans Green, London.

Bishop, M. W. H. \& Walton, A. (1960b) Metabolism and motility of mammalian spermatozoa. In: Marshall's Physiology of Reproduction, 3rd edn, Vol. 1, Part 2, p. 264. Ed. A. S. Parkes. Longmans Green, London.

DotT, H. M. \& Dingle, J. T. (1968) Distribution of lysosomal enzymes in the spermatozoa and cytoplasmic droplets of bull and ram. Expl Cell Res. 52, 523.

Garbers, D. L., Wakabayashi, T. \& Reed, P. W. (1970) Enzyme profile of the cytoplasmic droplet from bovine epididymal spermatozoa. Biol. Reprod. 3, 327.

Graham, E. F. \& Pace, M. M. (1967) Some biochemical changes in spermatozoa due to freezing. Cryobiology, 4, 75.

Harrison, R. A. P. \& White, I. G. (1969) Distribution and behaviour of some glycolytic enzymes in spermatozoa and cytoplasmic droplets from mammalian semen. Biochem. F. 111, 36P.

Harrison, R. A. P. \& White, I. G. (1972) Some methods for washing spermatozoa from bull, boar and ram: a comparison using biochemical and other criteria. F. Reprod. Fert. 29, 271.

KAmpschmidt, R. F., MAyer, D. T. \& Herman, H. A. (1953) Lipid and lipo-protein constituents of egg-yolk in the resistance and storage of bull spermatozoa. F. Dairy Sci. 36, 733.

ManN, T. (1964) Biochemistry of semen and of the male reproductive tract. Methuen, London.

MuRdoch, R. N. \& White, I. G. (1968) Studies of the distribution and source of enzymes in mammalian semen. Aust. J. biol. Sci. 21, 483.

Pickett, B. W. \& Komarek, R. J. (1967) Effect of cold shock and freezing on loss of lipid from spermatozoa. 7. Dairy Sci. 50, 753.

Pursel, V. G., Johnson, L. A. \& Gerrits, R. J. (1968) GOT and LDH enzyme activities in coldshocked and frozen boar semen. F. Anim. Sci. 27, 1788.

Pursel, V. G., Johnson, L. A. \& Gerrits, R. J. (1969) Effect of cold shock and freezing on cations of boar spermatozoa. F. Anim. Sci. 29, 196.

Quinn, P. J. \& WhITE, I. G. (1968) The effect of $\mathrm{pH}$, cations and protective agents on the susceptibility of ram spermatozoa to cold shock. Expl Cell Res. 49, 31.

Quinn, P. J., White, I. G. \& Cleland, K. W. (1969) Chemical and ultrastructural changes in ram spermatozoa after washing, cold shock and freezing. F. Reprod. Fert. 18, 209.

Wales, R. G. \& White, I. G. (1959) The susceptibility of spermatozoa to temperature shock. $\mathcal{F}$. Endocr. 19, 211. 